\title{
QUARTERLY ANALYSIS: \\ The Progress of Monetary, Banking and Payment System \\ Quarter IV - 2010
}

\author{
Author Team of Quarterly Report, Bank Indonesia
}

The economy of Indonesia in 2010 showed a quite high growth acceleration in the middle of the imbalance of global economic recovery. The domestic economy is forecasted to grow $6.1 \%$ in the fourth quarter of 2010 that in general, the national economy in 2010 grow about $6 \%$. For 2011 and 2012, Bank Indonesia is optimistic that the recovery of domestic economy will be stronger, supported by the increased domestic demand with a better investment performance. The Indonesian economy in 2011 is forecasted to grow up to 6.0 to $6.5 \%$ and in 2012 is predicted to become 6.1 to $6.6 \%$.

Bank Indonesia notes that the process of global economic recovery throughout 2010 has been continuing despite the slow down at the beginning of second half of 2010 and the uneven pace in different regions. Economic recovery of countries with emerging market is stronger than the one is developed countries, supported by solid domestic consumption and external performance which continues to improve. Meanwhile, the economy of developed countries that had improved in the first half of 2010, slowed down at the second semester of the year as the waning effect of fiscal stimulus, launched in 2009. In addition, the growth in advanced economy countries is also faced with a fiscal crisis in a number of European countries and the high rates of unemployment United States (U.S.).

The imbalance of economic growth has resulted in different monetary policy responses adopted by each country. The central banks of developed countries continue the accommodative policies which impact on the increase of global liquidity. Meanwhile, the central banks of emerging market countries conduct the policy normalization to resist inflationary pressures that keep growing along with economic recovery accelerated. These conditions have an impact on the strengthening of the exchange rates of emerging market countries, including Indonesia, which are then responded by using various combinations of policy instruments.

The performance of the global financial markets rebounded after the decision of the developed countries to maintain the accommodative monetary policy. The fiscal crisis that hit European countries (PIIGS-Portugal, Ireland, Italy, Greek/Yunani, and Spain/Spanyol) has reduced 
the appetite toward risk of global investors. This encourages investors to shift the assets at risk, including those of emerging market countries, which give a pressure to global financial markets. However, the pressure in financial markets began to ease and gradually recovered in the second half of 2010. Monetary policy signals of developed countries which maintain low interest rates and accompanied by monetary stimulus packages have been encouraging the rally on global stock markets world wide including in emerging markets.

The dynamics of the global economy throughout 2010 has an impact on the development of economy of Indonesia. The continuing global economic recovery continues, especially in countries with emerging markets and economic stability has a positive impact in accelerating domestic economic growth. The undertaken macro-economic policies have contributed to the internal and external balance in the Indonesian economy. This is an important factor to promote sustainable economic growth. The domestic economic growth this year is supported by a more balanced source of growth, and reflected in the high consumption and export demand and also the improved investment. Increased consumption comes primarily from household consumption, as governmental consumption is still relatively limited to the use of budgets. Export-wise, there was an improved performance in 2010 supported by the increased external demand as the global economic recovers, especially in Asia. The improvement in export performance was also driven by the increase in global commodity prices. Meanwhile, the investment performance has also continued to show improvement, supported by the improved market perception, increased funding, relatively low prices of imported goods, and implementation of various government policies that support investment.

From the supply side, both the non-tradable and tradable sectors show that an improved performance in 2010. Tradable sector growth mainly comes from the recovery in the manufacturing sector, which achieved a high growth of $4 \%$ before the global financial crisis. However, the improved performance of industrial sector is not followed by the performance of other tradable sectors. The agricultural sector is affected by decreasing productivity and the land area related to the weather anomaly. Meanwhile, the mining sector is also experiencing problems related to weather factors. On the non-tradable, the growth mainly comes from trades, hotels and restaurants, and also the transport and communications sector, while the other non-tradable sectors tend to slow down.

Regarding the prices, the year of 2010 was characterized by the tendency of rising inflationary pressures, mainly sourced from the volatile food. The high inflationary pressure from food groups (volatile food) due to weather anomalies caused a disruption of distribution and production. Inflationary pressures originating from the administered prices also rose, although limited. The increase in base electricity tariff (Tarif Dasar Listrik/TDL) in July 2010 did 
not push the commodity price to increase significantly. Core inflation pressures experience an increase, although still under control by the strengthening of the rupiah. This increasing inflation is derived from the trend of increasing commodity prices of global market. Meanwhile, the inflation expectation has also rose which could be influenced by the rise in food prices. With these developments, until November 2010, the CPI inflation stood at 6.33 (yoy) or reached $5.98 \%$ (ytd), while core inflation reached $4.31 \%$ (yoy) or at $3.89 \%$ (ytd).

The improved and continuing recovery of Indonesian economic in 2010 was also confirmed by the regional economic assessments conducted by Bank Indonesia. In general, the regional economy during 2010 continued to accelerate by the support of high consumption, exports and investment. Sumatra, Sulawesi, Kalimantan and Papua were predicted to have an increased economic growth resulted from the improved performance of plantations which are influenced by the improved price. At the same time, the performance of the mining sector, which operates in these regions, is predicted to be still limited due to anomalous weather and technical problems of production. The area of Jakarta, Java, Bali, Nusa Tenggara, and Kalimantan, is forecasted to experience high growth supported by the performance of manufacturing industry and construction sector. Investment activities in building construction grow up quite relatively high in Jakarta, Java, Bali and Nusa Tenggara.

The point of view of the balance of payments, export growth remains strong and capital inflows, whether in the form of Foreign Direct Investment (FDI) or portfolios that remain strong, bring an impact in improving the surplus of Indonesia's balance of payments. The global economic recovery that continues to progress, notably in countries with emerging markets has driven a strong growth in exports. The increase in global commodity prices also helped to encourage improvements in Indonesian exports with a greater share of natural resource-based commodities. On the other hand, the increase in the domestic economy and exchange rate appreciation has prompted a greater increase in imports. Meanwhile, global economic recovery that is not balanced has caused a large increase in foreign capital inflows. Overall, the balance of payments of Indonesia recorded a surplus in 2010 compared to the previous year. In line with this NPI development, the foreign exchange reserves of Indonesia by the end of November 2010 stood at USD 92.759 billion, equivalent to 6.96 months of imports and payment of foreign debts of the government.

The rupiah strengthened significantly in 2010. The strengthening of rupiah is supported by solid fundamental factors, reflected in the performance of the current account that records a significant surplus. In addition, the strengthening of the rupiah is also influenced by the rapid inflows of foreign capital associated with the abundance of global liquidity; strong expectations toward the continuing low interest rate policy in developed countries and the launch of the 
second phase of Quantitative Easing by the Fed. The rapid inflows of foreign capital is also driven by sustained perceptions of risk; positive sentiment in line with macroeconomic stability; under control financial system, high economic growth and the maintained fiscal sustainability. Under these conditions, throughout 2010, Rupiah has been appreciated at the average of $3.7 \%$ (y-t-d) or rose by $4.3 \%$ (p-t-p) compared to 2009. This reinforcement was followed also by the annual volatility level that decreased to $0.4 \%$ from previously $0.9 \%$.

Domestic financial markets showed an improved growth in 2010 along with economic growth that continues to accelerate. Monetary policy transmission has also improved as reflected from the interest rate response to interest rate of money and banking markets which continues to decline, as well as the increased credit expansion. On the bond market, the transmission of monetary policy is reflected in the decline of the yield on SUN (government securities) for all maturities. On the stock market, the price index showed a surge that brought the IHSG to the highest level of 3756.9 .

In the coming periods, the development of the domestic economy is expected to continue. Economic growth 2011 is estimated to accelerate and reach around 6.0\%-6.5\%. As for the economic growth in 2012, it is estimated to reach $6.1 \%-6.6 \%$. These growths were supported by household consumption that remains strong, improving investment and the solid export performance aligned with the strong growth in trading partners, especially in Asia. From the price side, Bank Indonesia predicts that the inflation in 2011 can be directed at the target range, which is $5 \% \pm 1 \%$ in 2011 and $4.5 \% \pm 1 \%$ in 2012. Nevertheless, the market has to remain aware of the various risks to the achievement of the inflation target and the macroeconomic outlook for the future, such as the high uncertainty of global economic recovery, the rising international commodity prices, and the swift inflow of foreign capital which possibly trigger a currency war. On the domestic front, these risks are associated with the increase in excess liquidity in the financial sector and the possible disruption of production and distribution of basic commodities. In this regard, Bank Indonesia will emphasize the application of policy mix of monetary and macro-prudential, and at the same time strengthen the coordination with the Government. Some steps are being prepared by Bank Indonesia to mitigate the negative impact of foreign capital inflows and simultaneously strengthen the resilience of the banking system, among others, related to the regulation of reserves (GWM valas) and vostro accounts (deposit account in Rupiah, possessed by the non-residents in domestic banks).

Based on these assessments and the economic outlook, the Bank Indonesia Board of Governors Meeting on December 3, 2010 has decided to maintain the BI Rate at 6.5\% with interest rate corridor of \pm 100 bps. The decision also considers that the level of the BI Rate at $6.5 \%$ is still consistent with the medium-term inflation target and regarded to be conducive 
to maintaining financial stability and promotes banking intermediation. The evaluation of the performance and prospects of the economy in general would lead to better conditions. Economic growth in 2011 and 2012 is expected to increase with a more balanced source of growth. 
This page is intentionally left blank 